\title{
UM DOCUMENTO ANONIMO DOS FINS DO SÉCULO XVIII SÔBRE RELAÇÕES COMERCIAIS ENTRE O BRASIL E PORTUGAL.
}

Editada periòdicamente pelo Secretariado da Propaganda Nacional, depois, Secretariado Nacional de Informações de Lisboa, de dois em dois meses, desde 1944 até 1948, a publicação "Documentos dos Arquivos Portuguêses que importam ao Brasil" teve por objetivo trazer à luz e divulgar documentos inéditos ou mal conhecidos sôbre o Brasil e Portugal existentes em bibliotecas e arquivos portuguêses. Documentos relacionados com a Etnologia, a Literatura, a Filosofia e, principalmente com a História.

Essa edição de material documentário, feita com algum cuidado no tocante à transcrição dos textos e à seleção das peças documentais tornou a publicação uma fonte de informações valiosas.

Destarte, foram publicados no segundo número da referida coleção às páginas 5 e seguintes (1), trechos de interessante documento anônimo, sem data, sôbre o comércio entre Portugal e Brasil em fins do século XVIII. O documento que se intitula Epitome das vantagens que Portugal pode tirar das suas Colonias do Brasil pela Liberdade do Comercio do Sal naquelle Continente, encontra-se na Biblioteca de Évora, arquivado sob o n.o 25 do Códice CXVI / 2-13 daquela biblioteca. Consta de um "caderno de papel" escrito por "autor anônimo", "dos últimos anos do século XVIII, na opinião do erudito Cunha Rivara", contendo "muitas observações sôbre a liberdade do comércio do Brasil". E' o que diz a respeito, a pequena nota da redação que serve de apresentação ao documento (2).

Em uma das nossas pesquisas históricas levadas a efeito nos arquivos do Rio de Janeiro, tivemos a oportunidade de encontrar no arquivo do Instituto Histórico e Geográfico Brasileiro, sob título "Conselho Ultramarino - Évora - tomo XIX, Arq. 1.2.38 - Códice CXVI / 2-13 a 25", uma cópia manuscrita e integral do referido documento intitulado "Epitome das vantagens que Portugal pode tirar das suas Colonias do Brazil pela liberdade do Commercio do sal n'aquelle Continente", entre as muitas que lá existem, encomendadas

(1). - Número sem a respectiva data, porém, pelos exemplares seguinte:s - 5 em diante - conclui-se ser de julho de 1944.

(2). - 0 documento em questão apresenta alguns cochilos na sua transcrição, por isso não podemos dizer que a cópia do original obedeceu a um cuidado absoluto. Entre êsses cochilos, citamos, à pág. 5: "Potoji", por "Potosi"; à pág. 7: "M. de Montes Opieu", por "M. de Montesquieu"; à pág. 7, ainda: "Ramtehadal", por "Kamtchadal"; à pág. 8, "Leves", por "Lery". O fato não desmerece, entretanto, o valor da publicação, pois as faltas verificadas săo poucas e passivas de correção por parte do leitor que entender do assunto. 
em Portugal por aquêle Instituto, quando da organização do seu arquivo.

O precioso manuscrito conservado no arquivo da Biblioteca pública eborense, com trechos publicados na coleção dos "Documentos dos Arquivos Portuguêses que importam ao Brasil", n. ${ }^{\circ} 2$, pg. 15, cuja cópia integral do manuscrito original encontra-se no Instituto Histórico e Geográfico Brasileiro, consta do seguinte:

1. ${ }^{\circ}$. - - Uma carta assinada por $F$., dirigida a um amigo que não conseguimos identificar, visando participar as vantagens que Portugal poderia auferir de "suas colonias do Brazil" caso fôsse estabelecida a liberdade do comércio do sal, entáo monopólio de Estado.

Sem data, a carta referindo-se à Revolução Francesa, prova ser dos fins do século XVIII.

2.0). - A seguir, inicia-se o "Epitome...", resumo ou sumário de um estudo sôbre as vantagens da liberdade do comércio do sal, ou melhor, do levantamento do monopólio do comércio do sal que se efetuou de Portugal para o Brasil sob forma de estanque real, desde os meados do século XVII (3). Nesse estudo, o autor descreve - Brasil, as condições geográficas, os aspectos da flora e da fauna, pintando-os com as mais vivas e brilhantes côres. Nesse ambiente, verdadeiro paraíso terrestre, é colocado o homem - o índio - um forte, sem maiores preocupaçóes do que "gozar a terra da Promissâo, regada do mel e do leite".

Adiante, o autor, referindo-se à produção do país, menciona a criação do gado vacum que " $(. .$.$) he tanto, que a maior parte delle$ só se matta para se the tirar a pelle (...)" e a abundância dos couros, do leite e da carne, desperdiçados pela falta de sal. O que não sucederia desde que fôsse livre o comércio daquele produto. Isto acontecendo, conseqüentemente, aumentando o número de criadores, proporcionalmente aumentaria o de agricultores e o Brasil poderia sustentar Portugal de carne, peixe, queijos, manteigas, como de pão e de todos os viveres: " $(. .$.$) as verdadeiras riquesas, os thesouros$ inexauriveis, mais ricos, que o Potosi".

Admite a precariedade do ouro e da prata "que não são de huma necessidade absoluta" e cujo valor depende "do arbitrio e da estimação dos homens", possuindo sòmente "huma comodidade representativa das cousas para huma maior facilidade do Commercio". Defende a tese de que o agricultor e o fabricante têm maiores probabilidades de aumentar a sua riqueza, do que os mineiros que muitas vêzes dependem đa sorte. A riqueza dos primeiros é " (...) certa, real c verdadeira" e dos segundos, "(...) huma riqueza d'accaso (...)". Em síntese, faz a apologia da agricultura e da indústria: "Sem a industria os fructos da terra não terão valor; e se agricultura he desprezada acabão-se as fontes do Commercio (...)".

(3). - Myriam Ellis - "O monopólio do sal no Estađo do Brasil (1631-1801). Contribuição ao estudo do monopólio comercial português no Brasil, durante o período colonial". Boletim n.o 14 da Cadeira de História da Civilização Brasileira da Faculdade de Filosofia, Ciênciias e Letras da Universidade de São Paulo, 197 da mesma Faculdade. São Paulo, 1955. Secção Gráfica da Faculdade de Filosofia, Ciências e Letras da Universidade de São Paulo, págs. 15, 16 e segs. 
Aponta, em seguida, as privilegiadas condições geográficas e politicas de Portugal na Europa, para a efetuação do comércio, bem como os aspectos favoráveis ao intercâmbio com as colônias da Africa e da Ásia e com as "(...) Colonias do Brasil". Referindo-se ao Brasil, ressalta a importância das excelentes condições geográficas do país, favoráveis ao desenvolvimento do comércio, país, onde "(...) tudo só espera pela mão do homem".

Trata, ainda, do conceito da riqueza dos Estados, "(...) fundos de terras" e "(...) effeitos moveis". Os primeiros significam a riqueza de cada Estado em particular e os segundos, dinheiro, bilhetes, letras de câmbio, ações de companhias, navios e mercadorias; são êstes últimos universais e "(...) o Povo que possue mais destes efeitos moveis, he o mais rico (...)". Os Estados aos quais falta o "(...) Comercio da Navegação ou são totalmente barbaros ou vivem na escravidão $(\ldots)$ ".

Aplicando êste conceito a Portugal, diz o autor, que não seriam o ouro, a prata, ou as pedras preciosas os fatôres de uma grande navegação entre a Metrópole e suas Colônias, pois “ $(\ldots)$ os proveitos da Navegação procedem das somas dos proveitos da agricultura, e das manufacturas (..."). Não sòmente a agricultura e as manufaturas influiriam para o desenvolvimento da navegação comercial, mas também a pescaria. "Huma Nação que não tem grandes pescarias não pode ter uma grande Marinha, nem mesmo um grande Commercio". Os holandeses e os inglêses, com a pesca ao arenque e ao bacalhau constituem exemplos. E a pescaria, excelente fonte de recursos estava, então decadente em Portugal; e também no Brasil. No Brasil, pcr falta de sal, em decorrência do monopólio.

A seguir, o autor entra em amplas divagações, sustentando as qualidades do indígena, comparando-o ao branco, apontando como benéficas as influências do meio tropical sôbre o homem e os demais sêres vivos. Acentua, também, a influência da pobreza sôbre o homem, obrigando-o " $(.$.$) afazer hum maior uso das suas forças na-$ turaes (...)" na luta pela vida. Aborda o problema da educação do índio. Tudo isto, para chamar a atenção para um possível e melhor aproveitamento do trabalho indígena, no sentido de uma colaboração eficiente no setor econômico. No caso, seria o seu aproveitamento em relação à pesca, à salga de peixes, ao comércio e à navegação. Os negros que até então serviam na marinhagem, substituídos pelo indio, poderiam ser encaminhados para a lavoura, contribuindo desta forma, para o desenvolvimento desta atividade.

Ainda mais. $O$ aumento da produção exigiria maior número de embarcações para o transporte e para o comércio dos gêneros; para tanto, poderiam ser aproveitadas as madeiras brasileiras, "(...) que athe agora se corrompiam, e destruião no lugar dos seus nascimentos, no meio d'aquelles grandes mattos: de huma extenção de mais de trinta mil leguas quadradas $(. .$.$) ". Aproveitadas, não só as ma-$ deiras como o linho e o cânhamo para o velame dos navios, como outros tipos de plantas fornecedoras de fibras próprias para a fabricação de cordas; a guaxima, por exemplo. 
Em síntese, na opinião do autor, o Brasil tudo possuia para a formação de uma respeitável marinha mercante: abundância de gêneros de primeira necessidade, de marinheiros, de madeiras de construção, excelentes portos, baías largas e abrigadas.

Conseqüentemente, a exportação dos gêneros das colônias para a Metrópole haveria de desenvolver uma grande exportação de manufaturas da Metrópole para as colônias. Os gêneros exportados das colônias seriam vendidos em Portugal a preços baixos e razoáveis. Abundância, alimentação barata, conseqüentemente, mão de obra barata para as manufaturas. A Metrópole vestiria as colônias que por sua vez, a sustentariam. Isto, em detrimento do "(...) contrabando do Estrangeiro (...)" que se aproveitava das deficiências da indústria portuguêsa.

Para terminar, diz o autor que, quanto mais gêneros fôssem importados das colônias pela Metrópole, esta não podendo consumí-los todos, nem podendo remeter iguais valores em manufaturas, ficaria devedora de suas colônias. Em compensação, exportaria aquêle excelente e ficaria credora dos estrangeiros que não dispensavam os produtos coloniais. Portanto, ganharia nas compras, nas vendas e nos fretes. Que devesse às colônias, contanto que fôsse credora dos estrangeiros. Teria por obrigação prestar às colônias todo o socôrro de que necessitassem para sua defesa e segurança. Em retribuição, as colônias deveriam se submeter a "(...) alguns justos sacrificios (...)": só poderiam comerciar diretamente com a Metrópole; não poderiam ter fábricas de sêdas e de lãs, sendo obrigadas a importar as manufaturas portuguêsas.

Quanto mais os interêsses portuguêses se ligassem aos das colônias, mais rica seria a Metrópole. Quanto mais devesse às colônias, tanto viveria mais feliz e mais garantida...

E' êste, portanto, o conteúdo do "Epitome das vantagens que Portugal pode tirar de suas colonias do Brasil pela liberdade do Comniercio do sal n'aquele Continente".

$O$ documento em questão, que demonstra a cultura de quem o escreveu, o estudo e o conhecimento do Brasil da época, suscita um problema - o da sua autoria.

Quem seria o autor dessas linhas que refletem influências fisiocratas da escola francesa de Quesnay, princípios da escola inglêsa de Adam Smith, embora ainda impregnados de um certo sabor mercantilista?

Em 1794, publicado pela Eeal Academia das Ciências de Lisboa, vinha à luz o "Ensaio Economico sobre o Comercio de Portugal e suas Colonias", obra de repercussão na Europa e de autoria do bispo D. José Joaquim da Cunha de Azeredo Coutinho (4), economista brasileiro, bispo e governador interino da Capitania de Pernambuco, tendo

\footnotetext{
(4). - Sérgio Buarque de Holanda - "Introdução" à Memfória sôbro o preço do Açúcar, de D. José Joaquim da Cunha de Azeredo Coutinho. Publicação do Instituto đo Açúcar e do Alcool, série Fistória II, Rio de Janeiro, 1946. Indústria Gráfica J. Lucena. Estudo publicado no "Brasil Açucareiro", números do dezembro de 1944 e janeiro de 1945.
} 
sido, também, diretor geral dos estudos e presidente da Junta da Fazenda da mesma capitania, em fins do século XVIII (5).

$O$ "Epitome sobre as vantagens que Portugal pode tirar de suas Colonias do Brasil pela liberdade do Commercio do Sal" tais semelhanças apresenta em relação ao "Ensaio Economico sobre o Comercio de Portugal e suas Colonias", que não pairam dúvidas sôbre a sua autoria, é de D. José Joaquim da Cunha de Azeredo Coutinho. O assunto, as idéias, as frases e as palavras são os mesmos, embora mais amplamente expostos no "Ensaio Econômico...", obra que ressaltou a importância do sal para a economia do Brasil colonial, que demonstrou o caráter prejudicial do monopólio, concorrendo para a extinção do pernicioso privilégio da Corôa portuguêsa (6).

Natural do distrito de Campos de Goitacases, nasceu José Joaquim de Azeredo Coutinho, a 8 de setembro de 1742. Filho de abastada e aristocrata familia de senhores de engenho, era o primogênito de Sebastião da Cunha Coutinho Rangel e de D. Isabel Sebastiana Rosa de Moraes. Foi educado no Rio de Janeiro, onde aprendeu as primeiras letras, gramática, retórica, belas artes, filosofia e teologia, tendo viajado, depois, demoradamente pelas capitanias do Rio de Janeiro e de Minas Gerais. Órfão aos vinte e seis anos, devido à sua primogenitura, passou a gerir o morgadio dos Azeredos, entrando em maior contacto com a vida rural do Brasil e seus problemas.

Em 1775, renunciou aos seus direitos em favor de um irmão e partiu para Coimbra, onde se dedicou à carreira eclesiástica e licenciouse em cânones.

Ocupou o cargo de deputado do Santo Oficio, de 1784 a 1794. Membro da Academia Real das Ciências de Lisboa, em 1791, data dêsse ano o seu interessante trabalho, "Memória sôbre o preço do Açúcar" que lhe abriu as portas daquela instituição. Dedicando-se a estudos sociais e econômicos, em 1794 publicou o "Ensaio Econômico sôbre o Comércio de Portugal e suas Colônias", que parece ter sido a sua obra prima, revelando o economista que foi ( 7 ).

Nesse ano, encontrava-se vaga a sé episcopal de Pernambuco e o príncipe D. João indicou o nome de Azeredo Coutinho para ocupá-la (8), sendo êle eleito em fins de 1794. Sagrado no início do ano seguinte, instalou-se no seu posto, em fins de 1798 (9).

(5). - Azeredo Coutinho foi nomeado bispo em 1794. Visconde de Pôrto Seguro - "História Geral do Brasìl", 3a. edição, tomo V, Companhia Melhoramentos de São Paulo, São Paulo, s-d.j págs. 81 a segtes. Ver também, Basílio de Magalhães "Economistas Brasileiros", Dỉesto Econômico, volume 32, julho, 1947, ano III, pág. 113.

(6). Basilio de Magalhäes, op. cit., pág. 113.

(7). - Padre Heliodoro Pires - "Azeredo Coutinho" - Revista do Instiuto Histórico e Geográfico Brasileira. Tomo Especial. Consagrado ao Primeiro Congresso de História Nacional. Rio de Janeiro, 1915. Imprensa Nacional, pág. 781. Ver págs. 786, 787, 188, 789, 790, 7911 e 792.

(8). - J. J. P. Lopes - "Biographia dos Brasileiros Distinctoa por Armas, Letras, Virtudes \& C.". Revista do Instituto Histórico e Geokráfico Brasileiro. Tomo VII, 2a. edição. Rio de Janeiro, 1866. Typographia de João Ignacio da Silva, págs. 106 e seguintes.

(9). - J. da C. Barbosa - "Biographia dos Brasileiros Distinctos pelas Sciencias, Letras, Armas e Virtudes - D. José Joaquim da Cunha de Azeredo Coutinho" 
Até a época de vir para o Brasil, conseguiu de D. Maria I a doação do colégio, da igreja e das alfaias que pertenceram aos jesuitas de Olinda, a mitra de Pernambuco e ocupou-se com os estatutos do Seminário de Olinda, que inaugurou solenemente a 22 de fevereiro de 1800 (10), para a instrução da mocidade (11).

O Seminário de Olinda revolucionou os métodos de ensino herdados dos jesuitas. Azeredo Coutinho, graças à cooperação dos padies do Oratório logrou substituir a velha orientação aristotélica por principios mais próximos ao pensamento da época. O Seminário foi considerado, então, como o melhor núcleo de instrução secundária no Brasil (12) .

Grandes serviços prestou à capitania o bispo Azeredo Coutinho, não só como prelado, mas também como educador, tendo sido diretor geral dos estudos, como governador interino em substituição a D. Tomás José de Melo e, como presidente da junta da fazenda (13).

De 1804 em diante, eí-lo fora do Brasil, a exercer suas atividades. Fôra nomeado bispo de Miranda e Bragança; depois, em 1806, de Elvas, em 1817, de Beja. Em 1818, foi inquisidor geral do Santo Ofício e, em 1821, eleito deputado às Côrtes Constituintes pelo Rio de Janeiro, ano em que faleceu (14).

No momento, o que mais nos interessa é a obra de Azeredo Coutinho. Legou-nos o prelado vários trabalhos, de cujas listas elaboradas por J. da C. Barbosa (15), por Inocêncio Francisco da Silva (16) e por Sacramento Blake (17) nos aproveitamos. São as seguintes:

1) "Memória sôbre o preço do açúcar", cuja primeira publicação data de 1791 , por ordem da Academia Real das Ciências de Lisboa.

2) "Ensaio Econômico sôbre o Comércio de Portugal e suas Colônias", cuja primeira edição data de 1794, também impresso sob os auspícios da Academia Real das Ciências de Lisboa. Reeditado com acréscimos

\footnotetext{
- Revista do Instituto Histórico e Geográfico Brasileiro. Tomo 1, 2a. edição. Rio de Janeiro, Typographia Universal de Laemmert. 1856, págs. 349 e seguintes.

(10). - Alvará de 22 de março de 1796. Padre Heliodoro Pires, op. cit., págs. 804 e 805 .

(11). - Idem, pág. 805 .

(12). - Sérgio Buarque de Holanda - "Introdução" à Memória sôbre o preço do Açúcat, de D. José Joaquim da Cunha de Azeredo Coutinho. Op. cit., pág. 16.

(13). - Ver Padre Heliodoro Pires, op. cit., pág. 806. Ver J. J. P. Lopes - "Biographia dos Brasileiros distinctos por Armas, Letras, Virtudes \& C.". Revista do Instituto Histórico e Geográfico Brasileiro. Tomo VII, 2a. eldição. Rio de Janeiro. Typographia de João Ignacio da Silva, 1866, págs. 106 e seguintes.

(14). - Sérgio Buarque de Holendał op. cit., págs. 16 e 17

(15). - Op. cit., pág. 351 .

(16). - Innocencio Francisco da Silva - "Diccionario Bibliographico Portuguez. Estudos de Innocencio Francisco da Silva applicaveis a Portugal e ao Brasil". Tomo quarto. Lisboa. Imprensa Nacional. MDCCCLX, págs. 385 e seguintes.

(17). - Aygusto Victorino Alves Sacramento Blake - Diccionario Bibliographico Brazileiro". Rio de Janeiro. Imprensa Nacional, 1898, págs. 475 e seguintes,
} 
e correções em 1816 e em 1828, na mesma tipografia da Academia (18).

3) "Estatutos do seminário episcopal de Nossa Senhora da Graça da Cidade de Olinda". Lisboa, na Tipografia da Real Academia das Ciências, 1798.

4) "Estatutos do Recolhimento de Nossa Senhora da Glória do lugar da Boavista de Pernambuco". Lisboa, na Tipografia da Real Academia das Ciências, 1798.

5) “Allegação juridica, na qual se mostra, que são do padroado da corôa, e não da ordem militar de Christo, as igrejas, dignidades e beneficios dos bispados do Cabo de Bojador para o sul, em que se comprehendem os bispados de Cabo Verde, S. Thomé, Angola, Brazil, India, até a China". Lisboa, 1804.

6) "Discurso sobre o estado actual das minas do Brazil". Lisboa, Impressão Régia, 1804 (19).

7) "Analyse sobre a justiça do commercio do resgate dos escravos da Costa d'Africa". Lisboa, na Oficina de João Rodrigues Neves, 1808 (20).

8) "Concordancia das leis de Portugal e das bullas pontificiais, das quaes umas permittem a escravidão dos pretos d'Africa, e outras prohibem a escravidão dos Indios do Brasil". Lisboa, 1808.

(18). - Sérgio Buarque de Hołanda, op. cit., pág. 20.

A Memória sôbre o preço do Açúcar está incluída em apêndice ès várias ediçães do Ensario..., como por exemplo a primeira edição que data de 1794, tendo sido publicada em 1791, no Tomo III das Memorias Economicas da Academia Real das Sciencias de Lisboa. (Lisboa, na Officina da mesma Academia. Anno M.DCC.XCI), págs. 381 a 391 . Foi publicada também na edição de dezembro de 1940 de Brasil Agucareiro, órgão oficial do Instituto do Açúcar e do Atcool, n. ${ }^{\circ} 6$, vol. VI, ano VII cuja separata vem precedida de uma "Introdução" de Sérgio Buarque de Holanda, op. cit.

(19). - Publicado, em parte, na Revista do Instituto Histórico e Geográfico Brasileiro, Tomo LXI, parte I. Rio de Janeiro, 1898. Imprensa Nacional, págs. 5 e seguintes. Publicação em parte, porque o Discurso sobre o estado actual das minas do Brasil consta de quatro capitulos: no primeiro mostra-se que as minas de ouro são prejudiciaes a Portugal: no segundo a necessidade que ha de se estabelecerem aulas de mineralosia mas praças principais das capitanias do Brasil: no terceiro apontase o meio de se facilitarem as descobrimentas da historia natural, e dos thesouras das colonias de Portugal: no quarto apontamse os meios de se aproveifarem as producopöes $e$ a agricultura do continente das minas, que alís já é perdido para o ouro". Innocencio Francisco da Silva, op. cit., pág. 385, n.0 3663. Na Revista do Instituto Histórico e Geográfico Brasileiro citada estão publicades sòmente duas partes correspondentes à primeira e à quarta da edição de 1804. Publicado também no Investigador Portugurez de Londres, cf. A. V. A. Sacramento Blake, op. cit., pág. 478. Ver notas 53 e 54 .

(20). - A. V. A. Sacramento Blake, op. cit., pág. 477, pensa que é a obra publicada no Rio de Janeiro, em $1838 \mathrm{com}$ o título Memoria sabre o commercio dos escravos em que se pretende mostrar que este trafego é parp eles antes um bem, do que um mal; escrito porm*: natural dos Campos dos Goitacazes, Rio de Janeiro, 1838. 
9) "Commentario para a intelligencia das bulas e documentos, que o Rev. Dr. Dionizio Miguel Leitão Coutinho, juntou á sua "Refutação contra a allegação juridica sobre o padroado das igrejas, e beneficios do cabo do Bojador para o sul", sobre a jurisdição dos Exmos. bispos ultramarinos, sobre o senhorio, e dominio das conquistas; e sobre a jurisdição do conselho de ultramar". Lisboa, na Oficina de Antônio Rodrigues Galhardo, 1808.

10) "Informação dada ao ministro d'estado dos negocios da Fazenda D. Rodrigo de Souza Coutinho acerca da queixa contra o bispo fizeram alguns professores de instrucção publica de Pernambuco". Lisboa, na Oficina de João Rodrigues Neves, 1808.

11) "Respostas dadas por D. José Joaquim d'Azeredo Coutinho, bispo de Elvas, então bispo de Pernambuca, ás propostas feitas pór alguns parochos d'aquella diocese". Lisboa, na Oficina de João Rodrigues Neves, 1808 .

12) "Defesa de D. José Joaquim de Azeredo Coutinho sendo governador interino da capitania de Pernambuco". Lisboa, na Oficina de João Rodrigues Neves, 1808.

13) "Exhortações pastoraes do bispo d'Elvas aos seus diocesanos, aos quaes recommenda a defesa da religião, do soberano, e da patria". Lisboa, 1811.

14) "Copia da carta q. a S. Mag. o senhor rei D. João VI (sendo principe regente de Portugal) escreveu o Bispo d'Elvas em 1816". Londres, impresso por W. Flint, 1817.

15) "Copia da analyse da bulla do Sanctissimo Padre Julio III de 30 de dezembro de 1550 que constitue o padrão dos Reis de Portugal, a respto. da união, consolidação e incorporação dos mestrados das ordens militares com os reinos de Portugal". Londres, impresso por T. C. Hansard, 1818.

16) "Memoria lida na Academia das Sciencias, em que se refutam as asserções de Mr. Thomás no seu "Elogio ao almirante Du Guay-Trouin", e de outros escriptores francezes que louvam a prudencia do mesmo almirante na tomada da praça do Rio de Janeiro (...)". Publicada na "Mnemosine Lusitana", tomo I, números XIII a XVIII.

17) "Colleç̧ão de alguns manuscriptos curiosos do exmo. Bispo d'Elvas, depois Inquisidor geral, dos quais posto que se tenham publicado alguns no periodico "Investigador portuguez" nos numeros de Fevereiro de 1812, e Septembro de 1815; outro no periodico "Mnemosine Lusitana" nos numeros 13, 14, 15, 16, 17 e 18, 
comtudo foram sem nome do auctor; outros que ainda se conservam manuscriptos, se vão agora fazer publicos, por meio da imprensa". Londres, impresso por L. Thompson, 1819 (21).

Esta coleção contém os seguintes opúsculos:

a) "Uma analyse á Ordenação do livro 3, tit. 85.".

b) "Copias das cartas que escreveu aos exmos. Generaes inglezes que mais contribuiram para a restauração de Portugal (...) em 1811".

c) "As exhortações pastoraes aos seus diocesanos em 22 de Junho de 1810 e de 2 de Abril de 1811".

d) "Cartas aos redactores do "Investigador" sobre os limites do Brasil, e sobre o augmento no valor da moeda".

e) "Problema sobre a direcção dos balões aerostaticos, com a sua Resolução".

f) "A Memoria refutatoria dG Elogio de Duguay-Trouin por Mr. Thomás" (22).

18) "Memoria scbre a entrada dos francezes no Rio de Janeiro no principio do seculo passado". Lisboa, 18 . .

19) "Copia da carta que um amigo lhe escreveu de Lisboa, com algumas notas, em resposta a outra que lhe remetteu o seu amigo da côrte do Rio de Janeiro" copiada no "Correio Brasiliense", numero de maio de 1817. Londres, 1819.

20) "Cópia da proposta feita ao bispo de Pernambuco, etc., e da resposta que elle deu ao "Investigador Portuguez" sobre os limites do Brazil pela parte do sul" (Sem designação de logar e anno).

Dessas obras, a que mais atrai o nosso interêsse no momento é o "Ensaio Econômico sôbre o Comércio de Portugal e suas Colônias", de que nos servimos para a identificação da autoria do "Epítome...". A orientação dêsses dois trabalhos é a mesma, o mesmo sucedendo com as idéias que, no "Epítome..." constituem uma repetição do "Ensaio...", sem dúvida escrita posteriormente, permanecendo no anonimato.

Para se poder atribuir a D. José Joaquim da Cunha de Azeredo Coutinho a autoria do "Epítome.", basta um confrônto com os assuntos abordados pelo "Ensaio..." em cujo indice, o que mais

(21). - Fai nosso desêjo efetuar uma pesquisa nessas duas coleções de periódicos, Investigador Portuguez e Mnemosine Lusitana, ao elaborarmos estas ligeiras notas sôbre a obra de Azevedo Coutinho. Foi infrutífera, entretanto, a nossa busca nas principais bibliotecas de São Paulo, onde não figuram nos respectivos acêrvos bibliográficos. Eis porque tivemos de nos contentar ùnicamente com as referências mencionadas.

(22). - Já publicada na Mnemosine Lusitena, tomo I, números XIII a XVIII. Ver - número 16 da lista de obras de D. Josél Joaquim da Cunha de Azeredo Coutinho. 
despertou a nossa atenção transcreveremos a seguir (23), tentando demonstrar a perfeita concordância com os tópicos abordados no "Epitome...":

\section{"PARTE I.}

Dos interêsses, que Portugál póde tirar das suas Colónias do Brazil.

CAP. I.

CAP. II.

Dá-se uma bréve idéa da grande fertilidáde do Brazil; do muito gádo principálmênte vacûm, que prodúzem aquêles campos, e da muita abundância dos pêixes daquélas Costas. pág. ........

Portugál pelo grande supérfluo que tem, e póde ter das suas Colónias, déve necessáriamênte promovêr o Comércio da navegasão ...................

CAP. III.

Portugál não póde ter uma grande marínha, ou seja de guérra, ou de Comércio, sem ter muitas pescarías ........

CAP. IV.

As pescarías são o mêio máis próprio para civilizar os Indios do Brazil, principálmênte os que abítam junto ás márgens dos grandes ríos, ou do már .

CAP. V.

Os fndios do Brazil são muito capázes de servír, não só na marínha do Comércio, mas também na de guérra ......

CAP. VIII.

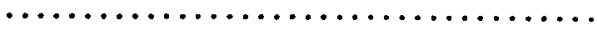

Para se fazêrem os navios de guerra, e de Comércio de Portugál, por um preso mais cómodo, e máis baráto, é necesário, que o Comércio das madêiras de construsão no Brazil seja lívre a todos os Nacionaes, e proibida a exportasão délas para os Estrangêiros, ou se-

CAP. IX. jão em bruto, ou fabricádas .........

Para adiantár o Comércio das madêiras do Brazil, é necesário que se extíngão os dirêitos, que délas se pagão de entráda neste Rêino ................

(23). - D. José Joaquim da Cunha ue Azeredo Cqutinha, op. cit., págs. I, II e III. 
PARTE II.

CAP. I.

Sobre os interêses, que Portugál póde tirar das suas Colónias nas três pártes do mundo.

CAP. II.

Portugál pela situação dos seus estabelecimêntos nas três pártes do mundo, póde fazêr relativamênte o Comércio ? máis átívo, e o máis vantajôzo de todas as Nações da Europa ...........

Portugál quanto máis devêr ás suas Colónias, tanto será mais rico .......

CAP. III.

As Colónias de Portugál quanto lhe fôrem máis crédôras, tanto lhe serão máis ligádas, e máis dependêntes .......

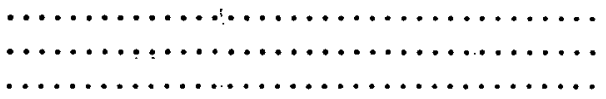

E não é só. A orientação das idéias é a mesma e idênticas são as palavras usadas em largos trechos de ambos os textos, como por exemplo as que iniciam as duas obras (24):

"A America he hum terreno abundantissimo: o Brazil he o mais abundante da America: debaixo de hum clima quente, mas doce, ameno, e temperado pelas chuvas e pelos ventos está sempre produzindo em hum continuo giro; a terra está em todo o anno cuberta de hum legre verde; e em huma primavera continuada: as Arvores estão sempre floridas, em cada huma dellas se vê ao mesmo tempo a flor, o fructo verde, e sasonado: (...)".

$\mathrm{E}$, nos mesmos têrmos - salvo pequenas diferenças - continuam os periodos seguintes do "Epítome..." correspondentes aos parágrafos números I, II, III, IV, VI. XIII, parte I, capitulo I, do "Ensaio...". Pequenas alterações existem de um texto para outro, como por exemplo o parágrafo IV do "Ensaio...", parte I, capitulo I, que corresponde ao seguinte trecho do "Epitome...":

"Aquelle precioso torrão produz immenso gado de toda a especie: o vaccum he tanto, que a maior parte delle só se matta para se lhe tirar a pelle; os muitos milhares de couros que todos os annos vem d'aquelle Continente fa-

(24). - Ver D. José Joaquim da Cunha de Azeredo Coutinho - Ensaio Econômico sóbre o Comércio de Portugal e suas Colônias. Publicado pela Academia Real das Ciências de Lisboa, na oficina da mesma Academia. 1794, pág. 1, parágrafo 1 . 
sem ver esta verdade, a abundancia do leite he em consequencia a proporção; a carne que alli se gasta, he nada em comparação da que subeja (25): as Aves, as feras, os tigres são os que se aproveitão do nosso superfluo (26): todo este desperdicio se faz pela falta do sál (27). Este genero da primeira necessidade para a conservação das Carnes, e dos pescados he n'aquelles Sertoens d'huma Carencia summa (28)".

Ainda mais. Adiante, em outro local, diz o "Epítome..." (29) em concomitância com o "Ensaio...":

"A abundancia, e o superfluo que sobeja do necessario de huma Nação, he a que forma o objecto do seu Commercio. A agricultura, e a industria são a esencia: a sua união he tal, que se huma excede a outra ambas se vem a destruir por si mesmas. Sem a industria os fructos da terra não terão valor; e se a agricultura é despresada acabãose as fontes do Commercio (30); deste Mar immenso, que anima e sustenta milhões de braços no meio da abundancia, sem aqual tudo cahe na lsinguidez, no ocio e na miseria (31)".

Ainda:

"Hum grande Commercio pede huma grande Navegação: mas como os proveitos da Navegação procedern das sommas dos proveitos da agricultura, e das manufacturas: segue-se que a Navegação he um dobrado augmento de forças reaes, e relativas de um corpo politico. Tudo quanto huma Nação ganha de huma parte diminue a potencia real e relativa das suas rivais e reciprocamente se augmenta de tudo quanto ellas perdem (32)".

A identidade de idéias e de expressões entre o "Epítome..." e " "Ensaio..." permanece no decorrer de ambos os textos, até os últimos parágrafos, embora o "Ensaio...", mais completo, aborde, minuciosa e amplamente, tópicos simplesmente mencionados no "Epítome...".

Ainda mais um exemplo:

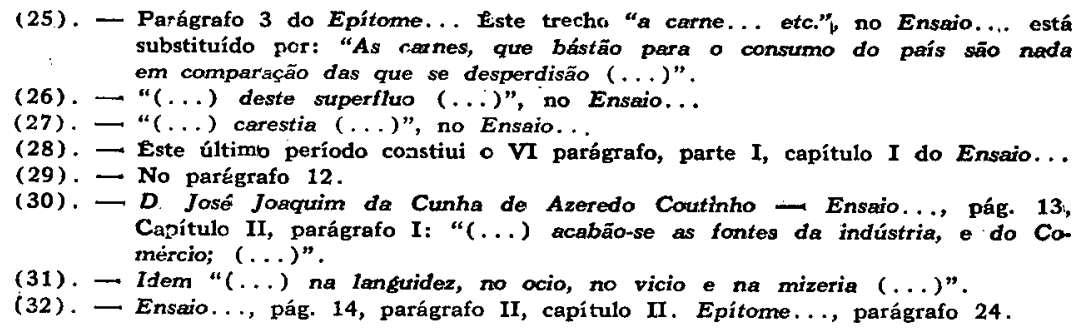
substituído por: "As cannes, qưe bástão para o consurmo do país saāo nada em comparação das que se desperdisão (...)". 
"A Metropole será sim devedora ás colonias; mas ella será em dobro credora aos Estrangeiros (33); ganhará nas compras, ganhará nas vendas, ganhará nos fretes, e nos transportes para todas as partes pela extenção da sua $\mathrm{Ma}$ rinha (34). Que importa que a Mãi deva a seus filhos (35), quando ella he em dobro credora aos Estranhos; (...)".

E:

"A Metropole por isso que he mãi deve prestar as Colonias suas filhas todos os bons officios e socorros necessarios para a defeza e segurança da sua vida (36), e dos seus bens, mantendoas em huma socegada posse, e fruição dessa mesma vida e desses bens. Estes beneficios pedem (37) eguaes recompensas, e ainda alguns justos sacrificios: e por isso he necessario que às Colonias tambem da sua parte sofrão; primeiro, que só possão Commerciar directamente com a Metropole excluida toda e qualquer outra Nação ainda que lhes fizessem (38) hum Commercio mais vantajozo. Segundo, que não possão as Colonias ter fabricas primeiramente de lãa e seda (39) e que sejão obrigadas a vestir-se das Manufacturas (40) da Metropole desta sorte os justos interesses e as relativas dependencias mutuamente serão ligadas.

Em huma palavra quantos os interesses e as utilidades da patria mãi se enlaçarem mais com os das Colonias suas filhas tanto ella será mais rica e quanto ella dever mais as Colonias, tanto ella será mais feliz, e vivira mais segura $(\ldots) "(41)$.

O confrônto de algumas partes dos dois textos apresentados confirmam com evidência a autoria do "Epitome das vantagens que Portugal pode tirar das suas Colonias do Brasil pela liberdade do Comemercio do Sal n'aquuele Continente". Não restam dúvidas, o autor é o bispo D. José Joaquim da Cunha de Azeredo Coutinho.

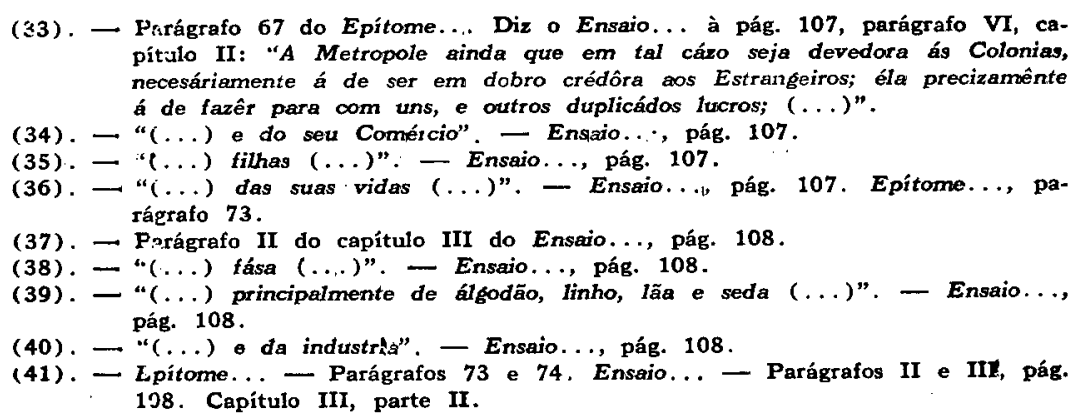


Entretanto, um outro elemento, ao qual não poderiamos deixar de nos referir, vem fortalecer a nossa afirmação, o "Discurso sobre o estado actual das Minas do Brasil", escrito por aquêle prelado, lido na Academia Real das Ciências de Lisboa, publicado em 1804 pela primeira vez em Lisboa, pela Impresa Régia e impresso em parte em 1898, na Revista do Instituto Histórico e Geográfico Brasileiro, tomo LXI (42).

Partes do "Discurso..." figuram no "Epitome..." integralmente, ou com algumas alterações. Assim, inicia-se aquêle com o trecho correspondente ao quinto parágrafo do "Epítome...":

"O homem pode viver sem Ouro e athe mesmo sem vestidos, taes são os Indios do Brasil; mas como ninguem pode viver sem alimentos, necessariamente a Nação produtora, e que mais abundar dos generos desta natureza, será sempre a mais rica, e della serão todos dependentes".

Mais adiante:

"O ouro porem, e a prata por isso que não são de huma necessidade absoluta (43) e só sim de huma comodidade representativa das cousas para huma maior facilidade do Commercio (44); vem a ter hum valor precario, ficticio, e dependente do arbitrio e da estimação dos homens; mas como a estimação dos homens cresce a proporção da raridade da couza, e deminue, a proporção da abundancia d'ella: assim tambem o ouro, e a prata representa e vale tanto menos, quanto elle se faz mais abundante".

Ainda, com pequenas modificações:

"O ouro, a prata, as pedras preciosas não occasionarão á Metropole uma grande navegação com as suas Colonias. Nem com outros povos: uma egual somma em carnes e peixes salgados, trigo, arroz, algodão, tabaco, assucar, caffé, linho, cánhamo, madeiras de construcção, mastros, etcetera, sustentará uma multidão infenita de Ma-

\footnotetext{
(42).' - "Discurso sobre o estado actual das Miras do Brasil, dividido em duas partes. Na primeira, mastra-se, que as Minas de Ouro são prejudiciaes a Portucal, não só pelo murto que já hoje o Estado perdo nellas, mas tambem pelos muitos braços que elles tirão á Agricultura. Na segunda apontão-se os meios de aproveitar a Agricultura do Continente das Minas que aliás é já perdido para o Ouro". Revista do Instituto Histórico e Geográfico Brasileiro, tomo LXI, parte I, pág. 5. Rio de Janeiro, Imprensa Nacional, 1898, com o titulo em maiúsculas, Memória sôbre as Minas de Ouro. (Ver a nota 19).

(43). - "O ouro e a prata tomados como signal por isso qưe nāo săo (...)". Discurso..., op. cit., pág. 6. Epitome..., parágrafo 6.

(44). - “(..) representativa do preço eminente de todas as cousas $(\ldots)$ ". Dis. curso..., idem.
} 
rinheiros, calafates et cetera. Hum dos malores objectos do Estado he dar que faser a um maior numero de homens possivel: a ociosidade e a indolencia, forão sempre as primeiras inimigas do bem publico" (45).

E:

"O Agricultor, o Fabricante, o Artifice, o Industrioso pode augmentar a sua riqueza a seu arbitrio, ou melhorando e apropriando o seu terreno para este ou aquelle genero de cultura, ou dando um maior movimento ao seu braço, ou augmentando a sua força por meio d'alguma machina; não he assim a respeito do mineiro: (46) a arte de formar da terra ouro ainda senão descubriu, a maior extracção d'elle não depende do braço do Mineiro depende do accaso, e muitas vezes o que menos trabalha é o que descobre o thesouro mais rico (...)".

Depois dêste estudo comparativo, acreditamos ter desfeito o anonimato do "Epitome das vantagens que Portugal pode tirar das suas Colonias do Brasil pela liberdade do Commercio do Sal n'aquelle Continente".

Quanto ao problema da data em que foi escrito, o documento pertence aos fins do século XVIII, não só pela alusão que faz à revolução na França, como principalmente pela referência ao monopólio do comércio do sal para o Brasil que sendo extinto em 1801 (47), ainda vigorava. O parágrafo 4 do "Epítome..." demonstra que a Corôa ia extinguir o monopólio e que Azeredo Coutinho aguardava o fato com grandes esperanças: "O Sal com que naquelles Sertoens se salga hum boi, custa duas e trez vezes mais, do que vale o mesmo boi, da mesma sorte o peixe: logo pois que seja livre o Commercio do Sál para aquelles Sertoens, o nosso superfluo não será para os Tigres: e como o Agricultor cresce a proporção do Creador virá logo o Brazil a sustentar a Metropole de Carne, peixe, pão, queijos, manteigas, e de todos os /viveres: ex aqui as verdadeiras riquesas, os thesouros inexauriveis, mais ricos que o Potosi".

Realmente, a Corôa, em fins do século XVIII cogitava de extinguir o monopólio do sal no Brasil e mandava consultar as Câmaras

\footnotetext{
(45). - Epitome..., parágrafo 29.

O Discurso... diz: "O ouro, a prata," as pedras preciosas não produzem uma grande navegação entre a Metropole e as suas Colonias, nem para com as outras Nações: uma igual scmma em trigo, arroz, algodão, tabaco, assucar, caffé, linho, canhamo, carnes, peixes salgados sustentará uma multidão infinita de marinheiros, carpinteiros, calafates, e outros muitos cuja ociosidade e pobreza constitue os primeiros inimigos do Estado".

(46). - Epítome..., parágrafo 8 .

Discurso..., op. cit., pág. 7 - "(...) a maior extracçāo do ouro não depende do seu braça, depende do acaso, muitas vezes o que menos trabalha é o que descobre um thesouro mais rico".

(47). - Myriam Ellis, op. cit., pág. 26.
} 
da Colônia sôbre o assunto (48). Esperava-se que o ano de 1799 assistisse à revogação do regime de estanque (49), o que foi feito sòmente em 1801 (50). Logo, o "Epítome..." é anterior. Certamente foi escrito depois do "Ensaio Economico sobre o Comercio de Portugal e suas Colonias" que data de 1794 e cujas idéias sem dúvida influiram na decisão régia de supressão daquele estanque (51). Azeredo Coutinho, certamente, aguardava o levantamento do monopólio do sal no Brasil quando redigiu o "Epítome..." que escreveu entre 1794 e 1801 , reproduzindo as mesmas convicções estampadas no "Ensaio..." (52).

Posterior ao "Ensaio...", o "Epítome..." é também contemporâneo ao "Discurso sôbre o Estado Actual das Minas do Brasil", publicado em Lisboa sòmente em 1804. Na fundamentada opinião de Sérgio Buarque de Holanda em sua "Introdução" à "Memória sobre o preço do Assucar" (53), o texto do "Discurso..." foi redigido alguns anos antes da sua publicação (54).

Apresentando idéias, períodos inteiros e inclusive os mesmos têrmos que figuram nessas duas obras de Azeredo Coutinho, o "Epítome..." encerra a essência do pensamento econômico do bispo.

(48). - Documentos Interessantes para a História e Costumes de São Paulo. "Officios do General Bernardo José de Lorena aos diversos funccionarios da $\mathrm{Ca}$ pitania. 1788-1795". (São Paulo, 1924, Duprat \& Comp.). Publicação Oficial do Arquivo do Estado de São Paulo, págs. 367 e 368. - "Portaria de Bernardo José de Lorena paì as Câmaras das vilas de Paranaguá e Mogi das Cruzes. São Paulo, 19 de junho de 1797".

(49). - Arquivo Pública do Estado de São Paulo - Maço Colonial 7 - Pasta 2 Documento 7 - "Oficio da Câmara de Bragança a Bernardo José de Lorena, de 1 de dezembro de 1798, pedindo 200 alqueires de sal e referindo-se ao fim do monopólio no ano seguinte". (Manuscrito Inédito).

(50). - "Alvará de 24 de abril de 1801". Colleç̧ão da Legislação Portuguesa desde a ultima compilação das Ordenaçóes. Redigida pelo Desembargador Antonio Delgado da Silva, vol. de 1791 a 1801 . Lisboa, 1828, Typog. Maigrense, pág. 694.

(51). - (52). - Myriam Ellis, op. cit.y págs 185 e 186.

(53). - (54). - Op. cit., pág. 29, nota 34. De 1804 data "Só a publicação, pois o texto estava parcialmente redigido ou esboçado alguns anos antes. $E$ ' sem dúvida um exemplar cêsse esboço o que existe com o mesmo título, sem data e sem nome de autor, entre os manuscritos da Biblioteca Municipal do Pôrto - Cód. 464 - (Veja-se Catálogo dos Manuscritos Ultramarinos da Biblioteca Pública Municipal do Pôrto, Lisboa, 1938, págs. 212 e seguintes). Não é impossível que tenha sido composto antes mesmo de publicar-se a Memória sôbre o preço do Açúcar, pois a fls. $5 \mathrm{~V}$. đo citado Ms., esta obra é referida com título diverso do que finalmente receberia. Talvez a leitura de Adam Smith tivesse movido o autor a refundir o escrito sôbre as minas, acrescentando-lhe, além disso, as duas partes que não figuram no códice do Pôrto e que correspondem à segunda e à terceira do volume publicado em 1804. Outro exemplar existe na Biblioteca Nacional do Rio de Janeiro, êste assinado e seguido de uma curiosa, Nota sôbre a divisäo de limites entre Portugal e Castella na América, onde se sugere uma demarcação pela qual o Brasil ficasse com todo o território an norte do Prata e a leste do rio $\mathbf{P a -}$ raguab, renunciando em favor dos castelhanos a parte do atual Estado de Mato Grosso e a tôdas as áreas ao norte do rio Amazonas. Desprezaria as minas pelo comércio, com o que - điz Coutinho - passariam os portuguêses a ser verdadeiros senhores do ouro de Mato Grosso, sel he $q^{\prime}$ ali ha algum e da prata do Potosi, pois he huma verdade demonstrada e feifa paipavel pela experiencia, $q^{\prime}$ a Nação que comerceia imediatamente com a Nação mineira do outro e da prata he sempre a mais rica relativamente". 
E' mais do que uma simples síntese do "Ensaio..." e do "Discurso...", de que foram extraídas cópias inteiras de trechos escolhidos, emendados e dispostos de forma a criar um novo trabalho exclusivamente decalcado naqueles - o que não diminui o seu interêsse. E' uma repetião das idéias expostas pelo prelado naquelas obras, fato que comprova incontestàvelmente a sua autoria.

\section{MYRIAM ELLIS}

Assistente da Cadeira de História da Civilização Brasileira da Faculdade de Filosofid, Ciências e Letras da Universidade de São Paulo.

EPITOME DAS VANTAGENS, QUE PORTUGAL PODE TIRAR DAS SUAS COLONIAS DO BRAZIL PELA LIBERDADE DO COMMERCIO DO SAL N'AQUELLE CONTINENTE.

\section{Meu Amigo.}

Não espereis que eu vos dê as tristes notícias da fea sena, que se representa no grande theatro da Europa onde apesar dos mais bellos planos de aumentar a população, de poupar a vida do homem, e de economizar as rendas publicas de cada Estado; se vê por huma parte boiar em rios de sangue muitas mil cabeças cortadas em hum instante, como de hum só golpe; por outra parte hum fogo surdo, que por baixo das sinsas se vai ateando assoprado por mil boccas. Não meu Amigo eu só vos quero dar alegre noticia de que agora se diz, que a nossa Soberana, a nossa Augusta Mãi, foi servida declarar que a venda do Sal, que em alguns Portos do Brazil he hum Contracto Real não comprehende os Portos do Rio Grande, e de Santa Catharina. Se vós alem dos vossos grandes conhecimentos especulativos tivesseis também o pratico d'aquelle Paiz, só esta simples narração vos faria ver o immenso campo, que hade produzir os nossos fructos; a vossa vista, ainda que de hum Lince se perderia sem duvida no seu largo horisonte sem limites.

Sua Magestade só por esta porta vai descobrir thesouros inexauriveis mais ricos que o Potosi; vai produzir hum Commercio immenso vai chamar nos seus Dominius $\mathrm{Na}-$ çoens inteiras que no meio do Ocio, e da indolencia nutrem huma barbaridade espantosa: vai crear huma Marinha formidavel aos seus inimigos: vai faser a felicidade de todos os seus vassallos; e firmar mais, e mais / se he possivel / a felicidade d'aquelles Povos. 
Não julgueis que são edeias ficticias de hum filho apaxonado, que tece Coroas das mais bellas flores para ornar a frente de sua Mãi; eu terei cuidado de vos hir lembrando os Escriptores, e viajantes Hespanhões, Francezes, Holandezes, e Alamães, que melhor do que eu vos dirão toda a verdade, e sem suspeita. Permitti porem que eu por esta vez possa interromper o vosso estudo com as presentes reflexões nas quaes vos pertendo mostrar em Compendio as vantagens que Portugal pode tirar das suas Colonias do Brazil pela liberdade do Commercio do Sal, naquelle Continente: Eu vos rogo como Amigo, que me communiqueis as vossas luzes sobre esta materia para ter a honra de aprender de vós o muito que ignoro: eu serei contente com a gloria de ter desafiado nesta parte as vossas reflexões em utilidade do bem publico, com o qual o nosso se acha tambem ligado. Não vos offereço a minha vontade por que ella deixou logo de ser minha desde que eu principiei a ser - Vosso Amigo. F.

EPITOME DAS VANTAGENS QUE PORTUGAL PODE TIRAR DAS SUAS COLONIAS DO BRAZIL PELA LIBERDADE DO COMMERCIO DO SAL N'AQUELLE CONTINENTE.

A America he hum terreno abundantissimo: o Brazil he o mais abundante da America: debaixo de hum clima quente, mas doce, ameno, e temperado pelas chuvas e pelos ventos está sempre produzindo em hum continuo giro: a terra está em todo o anno cuberta de hum legre verde; e em huma primavera continuada: as Arvọres estão sempre floridas, em cada huma dellas se vê ao mesmo tempo a flor, o fructo verde, e sasonado: os mattos produsem immensos fructos silvestres, d'onde nasce a immensa caça groça, e volatil, e athe immenso peixe, que se cria nos Rios, Lagos, e Mares, que bordão aquelle terreno delicioso, a grandesa d'aquelles peixes verdadeiramente monstros d'aquelles Mares, provão bem a fertilidade dos seus pastos; isto que se vê a respeito dos grandes, ahinda he mais a respeito dos pequenos.

Ali o Indio, aquelle homem barbaro e selvagem sem agrictultura, nem industria debaixo d'hum clima agradavel, e que o não incomoda, soberbo, e altivo com a força, e robustez do seu braço sem mais vestidos do que aquelles, que lhe deu a naturesa, vive e dorme descansado, sem já mais se lembrar d'onde lhe hade vir o sustento para o outro dia; o arco, e a flexa he toda a sua riquesa, he toda a sua industria: assim vivem centenas de milhares de homens sem trabalharem para comer, que parece nascerão 
só para gozar a terra da Promissão regada do mel, e do leite.

Aquelle precioso torrão produz immenso gado de toda a especie: o vaccum he tanto, que a maior parte delle só se matta para se lhe tirar a pelle; os muitos milhares de couros que todos os annos vem d'aquelle Continente. fasem ver esta verdade, a abundancia do leite he em consequencia a proporção; a carne que alli se gasta, he nada em comparação da que subeja: as Aves, as feras, os tigres são os que se aproveitão do nosso superfluo: todo este desperdicio se faz pela falta do Sál. Este genero da primeira necessidade para a conservação das Carnes, e dos pescados he n'aquelles Sertoens d'huma Carencia summa.

O Sál com que naquelles Sertoens se salga hum boi, custa duas e trez vezes mais, do que vale o mesmo boi, da mesma sorte o peixe: logo pois que seja livre o Commercio do Sál para aquelles Sertoens, o nosso superfluo não será para os Tigres: e como o Agricultor cresce a proporção do Creador virá logo o Brazil a sustentar a Metropole de Carne, peixe, pão, queijos, manteigas, e de todos os viveres: ex aqui as verdadeiras riquesas, os thesouros inexauriveis, mais ricos, que o Potosi.

$O$ homem pode viver sem Ouro e athe mesmo sem vestidos, taes são os Indios do Brazil: mas como ninguem pode viver sem alimentos, necessariamente a Nação productora, e que mais abundar dos generos desta naturesa, será sempre a mais rica, e della serão todos dependentes. $O$ vestuario por isso que se consome a proporção das necessidades reaes, e das ficticias do mero gosto e do luxo; assim tambem a Nação fabricante, e industriosa terá sempre huma riquesa mixta, e limitada relativamente ao gosto, e a necessidade.

O ouro porem, e a prata por isso que não são de huma necessidade absoluta; e só sim de huma comodidade representativa das cousas para huma maior facilidade do Commercio; vem a ter hum valor precario, ficticio, e dependente do arbitrio, e da estimação dos homens: mas como a estimação dos homens cresce a proporção da raridade da couza, e deminue, a proporção da abundancia d'ella: assim tambem o ouro, e a prata representa, e vale tanto menos, quanto elle se faz mais abundante.

No tempo do Senhor Rei Dom Manoel, um vintem valia, e representava hum alqueire de trigo, hoje porem, que a massa geral do Ouro se tem augmentado, vinte vezes, e mais; já vinte vintēis não valem, nem representão huma egual porsão de trigo d'aquelle tempo; logo he evidente que a Nação Mineira, quanto ella augmenta mais o seu genero, tanto ella dá menos valor, e menos representação a sua riquesa; e assim por huma progressão conti- 
nuada, quanto ouro ella cava, tanto mais cava a sua ruina, e se faz mais dependente do harbitrio das outras. Felippe segundo o Senhor de todo o Potosi fez huma banca rota e vergonhosa, o seu Ouro, e a sua prata secumbio aos arranques da Holanda.

O Agricultor, o Fabricante, o Artifice, o Industrioso, pode augmentar a sua riqueza a seu arbitrio, ou melhorando e apropriando o seu terreno para este ou aquelle genero de Cul'ura, ou dando um maior movimento ao seu braço, ou augmentando a sua força por meio d'alguma maquina; não he assim a respeito do mineiro: a arte de formar da terra ouro ainda se não descubrio, a maior extração d'elle, não depende do braço do Mineiro depende do accaso, e muitas vezes o que menos trabalha é o que descobre o thesouro mais rico: estas riquesas de casualidade, e de mera representação, não poderão já mais entrar em comparação com as necessidades reaes, e urgentes de todos os dias; e desta sorte vem a Nação Mineira a ter huma riqueza d'accaso, quando as outras a tem certa, real, e verdadeira.

Sei que todas as Nações Civilisadas sem exceptuar, nem ainda aquellas, que meihor tem calculado os interesses do Ouro, não só não tem despresado as Minas d'este metal, mas tem feito, e fasem todas as diligencias por descobri'las nas suas terras. Sei que o ouro se tem feito procurar pelas entranhas da terra, pelo meio das ondas, e athe por cima das nuvens; sei que elle tem franqueado a communicação de todos os povos, que os tem civilisado, que tem creado, e nutrido as sciencias, as Artes, que elle em fim se tem feito o presso emminente, e representativo de todas as cousas.

He necessario porem confessar, que o ouro só he bom para o que Commerceia com elle, como genero, mas não para o Mineiro, ou para aquelle que o extrahe da terra, excepto no caso, em que a sua Mina he tão rica que todos os annos lhe vai sempre produzindo mais / o que he raro / de sorte que em tanto por huma parte elle for perdendo, na representação do seu ouro, ou do seu genero pela abundancia que elle vai acumulando na massa geral do Commercio, vá ganhando pela outra parte no augmento da quantidade do seu genero logo que a sua Mina lhe produsir todos os annos a mesma quantidade, elle irá sempre perdendo por huma parte na representação do seu Ouro, sem nada ganhar pela outra parte no augmento da quantidade: e quando a sua mina lhe for produsindo menos como hoje succede nas nossas minas / elle irá sempre perdendo por huma, e outra parte athe se achar de repente sem ter que comer, nem vestir, nem cousa que 
o valha; he pois necessario antes que chegue este dia fatal, voltar para a agricultura.

A seda em rama, o omenen, a coxunilha, a purpura, o anil, a canella, a baunilha, o cacáo, o Caffé etcetera. A quina, a Ipecacuanha, e outros muitos generos medicinais são excellentes producções para as terras mais do interior d'aquelle Continente: o seu muito valor a respeito do seu peso pode bem compensar as despesas dos transportes d'aquelle Certões para os portos do Mar: os mesmos gados creados n'aquelles campos poderão carregar todos estes generos, e serem vendidos a borda dos grandes Rios, ou do Mar juntamente com as suas cargas.

A abundancia, e o superfluo que sobeja do necessario de huma Nação, he a que forma o objecto do seu Commercio. A agricultura, e a industria são a essencia: a sua união he tal, que se huma excede a outra ambas se vem a destruir por si mesmas. Sem a industria os fructos da terra não terão valor; e se a agricultura he despresada acabão-se as fontes do Commercio; deste Mar immenso, que anima e sustenta milhões, e milhões de braços no meio da abundancia, sem aqual tudo cahe na languidez, no ocio e na miseria.

O Comercio tem feito grandes a muitas Nações: nenhuma porem está nas circunstancias de o faser tão grande como Portugal pela feliz situação em que a natureza pos os seus Estados em todas as quatro partes do Mundo: na Europa está Portugal na parte mais occidental de baixo do melhor clima, cercado por huma parte d'hum Mar immenso com Portus francos, e abertos para todo o Mundo: pela outra cercada de huma Nação Amiga, governada por hum Soberano, que sabe, que a felicidade de hum, e outro Estado consiste na boa harmonia d'ambos.

Todos os Estados da Europa não podem economisar bastantemente as suas receitas, e despezas: por que alem das despesas annuaes, e da sustentação das suas tropas em tempo de paz, lhe he necessario ter sempre hum fundo como amortizado, e perdido para qualquer ataque de guerra inopinada: Elles estão como encravados huns nos outros sempre cheios de susto; qualquer choque de huma parte os abala, e faz tremer a todos; a prezente guerra da Europa faz ver a especie de convulsão, em que se achão quasi todas as Potencias do Norte.

Portugal porem situado em um canto esta como livre de todo o choque, rodeado de dois Amigos, hum que the franqueia todos os paços; o outro que pela sua grande massa lhe serve como de baluarte para rebater os contra golpes do Norte: As nações rivaes são as mesmas que se empenhão na conservação de Portugal: o seu Commercio, os seus Portos são preciosos a todos. 
Na Africa as Colonias Portuguesas estão no meio de huma Costa dilatada: Portugal que abrio d'Africa aos outros Povos, sempre n'ella conservou vantagens consideraveis apezar da sua decadencia; e ainda hoje possue grandes Estabelecimentos nas Costas as mais favoraveis ao Commercio dos Escravos: as Nações rivais só tem ali fracas feitorias, das quaes athe muitas vezes são privadas: estas posseçoens exclusivas, que nos procurão os Negros a hum melhor mercado, do que nos Portos, em que elles são comprados em concurrencia, darão sem duvida hum maior numero de braços para agricultura das Colonias do Brasil.

$\mathrm{Na}$ Asia ainda existem alguns Portos que fiserão a antiga grandeza de Portugal. Na America estão os Dominios Portuguezes na melhor parte d'ella. Todas as outras Nações tem as suas terras n'aquelle Continente, ou chegadas para os Polos, ou para a Equinocial da parte do Norte.

As terras chegadas para os Polos, por causa dos muitos frios, e das neves só dão huma producção em cada hum anno, e muito vagaroza, e tardia: as grandes bahias, e os grandes Rios, que lhes dão Portos estão em muita parte do anno gelados, e sem Navegação; taes são os principais Rios da America Setentrional. As outras terras mais chegadas a Equinocial da parte do Norte; ainda que são d'huma melhor producçáo comtudo estão sujeitas a tempestades horrozosas, e a furacoens de ventos tão fortes, que arrancão as arvores, e as searas inteiras, tal he a situação das Antilhas.

As terras da Contra Costa que 'bordão as margens do Mar do Sul desde o extreito de Magalhães athe os fins do Norte da California ainda são peores para a agricultura. O Reino do Perú tão celebrado pela riqueza das suas Minas de prata do Potosi, e do ouro da Caravaya figura muito pouco na fertilidade dos seus campos.

Dividido em tres partes a primeira forma a planice, ou o baixo Perú por toda a Costa junto ao Mar; a segunda, ou media, se compoem d'altos montes, e profundos vales; a terceira ou altissima, comprehende huma Montanha continuada, e sem vales denominada a Cordilheira, ou a grande serra dos Andes, a mais alta do Mundo. A primeira e terceira são quasi estereis: a primeira por que nella não ha chuvas, nem orvalhos, nem trovoadas: a terceira por que está sempre coberta de gelos eternos sem arvore alguma; a segunda ainda que produz alguns pastos para as criaçôes dos gados não he com tudo egualmente fertil para a agricultura. No baixo Peru desde a Provincia de Chili athe Quito pela distancia de mais de quinhentas milhas são quasi continuos os terremottos. Em vinte oito de Outubro de mil settecentos quarenta e seis 
houve alli hum tam grande que se fez sentir por toda aquella Costa, o que ainda pareceo mais terrivel, e espantozo pela violenta agitação do Mar do Sul cujas agoas subirão a huma altura extraoráinaria. A Illha de Calhao athe então lugar da residencia dos Vice Reis d'aquelle Estado, foi inteiramente submergida com a Cidade d'este nome, a qual ficava distante de Lima duas legoas, e passava pelo melhor Porto d'aquelle Paiz.

Thesouros immensos, armazens cheios de todo o genero de riqueza, Navios carregados das mais preciosas mercadorias do Peru, do Chili, do Mexico, forão engulidos no curto espaço de poucas horas. De huma multidão de Hespanhóes, e de Indios, de homens livres, e de Escravos, de habitantes de Calháo, ou de Estrangeiros, que - Commercio ali tinha chamado, hum só não escapou ao Naufragio. A larga esperiencia de tantos terremotos, e de nenhumas chuvas tem ensinado aos habitantes d'aquella Costa a faserem as suas Cazas de materiaes muito leves, sem telhados, mais do que huma pouca de palha coberta orizontalmente de alguma argila.

Supondo porem q. hajão alguns terrenos ferteis por aquella Costa; com tudo a sua agricultura he quasi como perdida para o Commercio das outras partes do Mundo. Hum Már immenso, huma dilatada e perigosa Navegação, ou seja pelo estreito de Magalhaens, ou pelo Cabo de Horn serão barreiras invenciveis, e que apartarão para sempre aquelles Colonos d'entrar em concurrencia com a nossa agricultura, e com a extração das nossas produções. Isto mesmo fará que a pesca das Baleias, que tem feito armar Nações inteiras, nunca já mais poderá concorrer com a nossa, dada a mesma industria, e actividade.

O Brasil está situado na parte mais Oriental da America, quasi no meio do Mundo como olhando para a Africa, dando hum braço à Europa, e outro a Asia: os seus Portos sempre abertos em todos os tempos do anno sem gelos, sem furacoens de ventos dão huma Navegação mais comoda e mais breve: em huma palavra a riquesa, e abundancia, que a Providencia espalhou por todas as partes alli estão todas juntas como em hum centro. A Holanda sem terra, submergida nas aguas, lutando contra os Elementos, só o seu Commercio a tem feito grande: no Brasil porem o Ceo, a terra, todos os Elementos concorrem a competência para a sua fertilidade e riqueza. Nada alli falta tudo só espera pela mão do homem.

Hum grande Commercio pede huma grande Navegação: mas como os proveitos da Navegação procedem das sommas dos proveitos da agricultura, e das manufacturas: segue-se que a Navegação he um dobrado augmento de forças reaes, e relativas de hum corpo politico. Tudo 
quanto huma Nação ganha de huma parte diminue a potencia real, e relativa das suas rivais, e reciprocamente se augmenta de tudo quanto ellas perdem.

Estes interesses respectivos obrigão as Nações Civilizadas a entreter com grande despezas forças Navaes capazes não só de proteger o superfluo da sua agricultura, e da sua industria (unicas raizes destas forças) mas tambem de perturbar, ou mesmo de arruinar a industria dos seus inimigos: e como o Commercio he o que poem estas forças em movimento pela abundancia dos Marinheiros que elle tem nutrido, e formado no tempo da paz: he claro que huma Nação civilizada não pode subsistir sem o Commercio da Navegação.

As riquezas dos Estados consistem, ou em fundos de terras, ou em effeitos moveis: os fundos de terras por isso que pedem mais assistencia, e a vista de seus donos, são ordinariamente possuidas pelos habitantes de cada Paiz, e constituem propriamente a riquesa de cada Estado em particular. Os effeitos moveis como são o dinheiro, bilhetes letras de Cambios, acçoens sobre as Companhias, Navios e todas as Mercadorias, por isso que são universaes, e giráo por toda a parte, pertence ao Mundo inteiro, que a este respeito compoem um só todo de que todas as outras Sociedades são membros: o Povo que possue mais destes efeitos moveis do Universo, he o mais rico; por que entra com um maior fundo, ou (expliquemo-nos assim) com um maior numero d'acçoens na grande Companhia do Commercio Universal.

Hum Estado que tem poucos, ou nenhum destes effeitos moveis; ou não deve Comerciar com os outros Estados, ou deve viver sem liberdade: pois que sendo como he o fim do Commercio faser das cousas superfluas uteis, e das uteis necessarias; augmentando um maior numero de necessidades a um Povo, que só vive das suas terras nunca já mais poderá ter um superfluo d'agricultura tam abundante que possa saldar, ou por em equilibrio, o seu superfluo, com o seu luxo sem que se vá sempre a empobrecer por uma economia forçada.

Mas como aquelle, que no Commercio paga menos, vai recebendo menos; virá a um tal estado por esta progressão a acabar finalmente em uma pobresa summa, e a não serem os seus habitantes mais do que uns pobres e mizeraveis Colonos das outras Naçoens: logo he necessario, que um tal Estado, ou não tenha Commercio com as outras Naçoens e por consequencia, que não tenha luxo e que só viva contente com a abundancia, e fertilidade do seu terreno, ou que a maior parte dos seus abitantes sejão escravos, ou que só virão absolutamente do simpies necessario para sustentar o luxo da piquena parte dos 
seus Senhores. As historias das viagens de todo o Mundo nos fazem ver constantemente, que os Estados, que vivem reconsentrados sem o Commercio da Navegação, ou são totalmente barbaros ou vivem na escravidão.

O ouro, a prata, as pedras preciosas não occasionarão à Metropole uma grande Navegação com as suas Colonias. Nem com outros Povos: uma egual somma em carnes e peixes salgados, trigo, arroz, algodão, tabaco, assucar, caffé, linho, cánhamo, madeiras de construcção, mastros etcetera, sustentará uma multidão infenita de Marinheiros, Calafates et cetera. Hum dos maiores objectos do Estado he dar que faser a um maior numero de homens possivel: a ociosidade e a indolencia, farão sempre as primeiras inimigas do bem publico.

A coragem d'atravessar os Mares, de os correr d'um Polo, a outro Polo, não tem sido negocio d'um dia: os homens só o teem adquirido à força de muitas experiencias pelas quaes elles se tem familiarizado com este Elemento tão inconstante, e tão terrivel, a pescaria foi sem duvida a que traçou as primeiras regras da Arte. Este ramo precioso d'occupação dos homens conserva a inda os seus direitos sobre a Navegação; pois que elle he sempre o berso e a eschola mais segura dos Marinheiros.

Huma Nação que não tem grandes pescarias não pode ter uma grande Marinha, nem mesmo um grande Commercio. Os Holandezes pela sua pesca d'arenque ganhão todos os annos milhoens de florins; os Inglezes pela sua pesca de bacalháo adquirem muitos centos de libras Esterllinas: elles pela sua pescaria tem a Marinheiros, tem Marinha, tem Commercio; tem dinheiro. A pescaria, esta fonte de riqueza inexaurivel, era quasi como perdida para Portugal, e para o Brazil pela falta do Sal: mas logo que este for livre, aquella irá chamar immensos Povos para os Dominios de Portugal.

Os Escriptores, que do fundo dos seus gabinetes presumem dar Leis ao Mundo sem muitas vezes tratarem de perto os Povos de que fallão; nem conhecerem os seus costumes, e os seus vicios, nem as suas paixões dizem que he necessario introduzir a ambição nos Indios d'America para os faser entrar no Commercio, isto he suppor que elles não tem ambição: he um engano, elles tem virtudes, tem vicios, são Amigos da gloria. São ambeciozos como nos.

Muitos d'elles sustentão o heroismo em summo gráo, a inda quando estão proximos a serem mortos, e devorados pelos seus inimigos, os insultão e desafião com desprezo significando d'este sorte, que ainda que lhes despedacem os corpos nunca ja mais poderão abater o valor, e a coragem d'um só da sua Nação, elles morrem em he- 
roes. Os Indios Ouctacazes são tão guerreiros, que he mais facil matal'os do que vencel'os: elles tem horror à um só instante de vida de baixo da escravidão: Nenhuma Nação Brazilense nem Europea pode athe agora cantar a gloria de os ter vencido, elles ainda se conservão livres, e independentes.

Os Indios do Brasil, assim como tem vicios, tem virtudes bem dignas de serem imittadas pelas Naçoens civilisadas, elles são geralmente cheios de caridade huns para os outros, a inda para com os Estrangeiros seus amigos e são summamente agradecidos aos seus bemfeitores, elles tributão huma fidelidade sincera, e verdadeira.

Por estes, e outros muitos exemplos de força e de coragem dos Indios do Brazil se vê o quanto se enganou Mr. de Montesquieu, Livro 14 Art. 2 em quando pertendeu mostrar que o homem do Paiz frio he mais forte e mais animoso do que o do Paiz quente sem reflectir que o homem nascido, e creado no meio dos ardores do Sol tem a fibra e o temperamento proprio do seu Paiz, e que nelle vive tão forte, e tam agil, como outro nascido e creado no meio dos gellos: seria sem duvida hum erro, e huma imprefeição da natureza, se assim não fora: comparecese a força, e a coragem de hum Indio Ouctaça, nascido e creado de baixo da Zona torrida com a de hum Indio Eskimo nascido e creado no meio dos gelos do Norte; comparece-se a força de hum Indio $\mathrm{O}-\mathrm{W}$-hi-e nascido e creado de baixo da Zona torrida, que pelo meio das bayonetas, e das ballas d'arthelharia Ingleza fez em postas e devorou - General Inglez seu inimigo: comparece-se digo a força, e a coragem de hum destes Indios com a posillanimidade de hum Kamtchadal coberto de neve nos fins da Siberia: passaudo aos irracionaes compare-se a força e a coragem de hum Leão das planíces do Zaara com a de hum Lobo da Filandia, ou com a de hum Urço de Laponia: em geral fallando dos animais, que os de Paizes quentes são mais guerreiros e mais fortes do que os de Paizes frios, e temperados: compare-se a força de hum pau ferro, de hum Ypé, de hum Sucupira das Margens do Rio das Amazonas com a de hum Carvalho e de um Pinho, de hum Bucho das Margens do Nieper: a naturesa que em todas as suas produçoens debaixo da Zona torrida se mostrou forte, tanto a respeito das couzas animadas, como das inanimadas, que modificou, e trabalhou a terra por tantos modos athe reduzida a ouro, e a agoa, a diamante nos curações dos roxedos se havia de mostrar fraca, e degenerado a respeito do homem, o primeiro objeto da sua creação! Lery e seus companheiros nascidos, e creados na Zona temperada não poderão dobrar hum só Arco dos Indios da Zona torrida dos contornos do Rio de Janeiro. 
Lery Cap. 13 do mesmo que confessa, que as forças de cada hum do seus companheiros apenas igualavão as de hum d'aquelles pequenos Indios de dez annos. = Arcus in super habent / Barbari Brazilienses / quos Mr. de Montesquieu pertendeu descobrir a razão se elle não tivesse confundindo as forças naturaes do homem, isto he aquellas que são necessarias para o movimento da sua maquina com as forças adqueridas pelo continuo uzo, e exercicio do trabalho, considere-se o rico da Corte, farto, e abundante, e o pobre d'Aldeia, ambos debaixo do mesmo clima, e se verá que o da Aldeia, a inda que cheio de fome he sempre proporcionalmente mais forte, não por força do temperamento ou do Clima, mas sim pela necessidade, e pobreza, que o obrigou sempre desde pequeno afazer hum maior uso das suas forças naturaes, e adquire delle huma certa fereza, e barbaridade; o rico por que se vêem um Paiz mais fertil, por isso que vive farto, faz um maior uso das potencias da Alma, e se faz mais afavel, e mais hum ano, e pelo contrario huma Nação pobre he quasi necessariamente guerreira; por que a sua pobresa mesma, cujo peso a importuna sem cessar, e poem em huma continua lucta, athe conspira sempre o dezejo de se liviar da pobreza, que afflige: e este dezejo se faz com o tempo - espirito geral da Nação athe q. faz huma errupção sobre hum Povo que vive na abundancia: esta continua lucta, ou esta força adquirida gradualmente e não a força natural do homem he que tem feito o pobre, rico, que tem mudado o estado das couzas, e a que tem transformado os Imperios, enfraquecidos pela naturesa do luxo: a nova Roma ainda existe debaixo do Clima da antiga, e contudo quanto distancia não ha da força, e da coragem huma da outra!, ella saberia fazer homens para os Paizes frios, mas não para os quentes.

O Homem he naturalmente ambiciozo, amigo da honra, e da gloria: este fermento de que a naturesa formou a sua Massa he que o faz obrar com força e actividade: a honra he um ente imaginario, a que todos haspirão, mas nem todos a veem pela mesma face, aquillo que a hum se representa como honra, a outro se representa como vileza, he hum idolo em fim, a que cada, hum prodigalisa insensos a seu modo: o homem selvagem adora a tirania, e a crueldade, o homem civilisado adora a beneficencia e a humanidade 120 - Lery: Cap. 5 - Ouctacatas.

Pelo que pertence aos bens se posto aquelle Indios necessitão de poucas couzas, com tudo essas de que elles necessitão / assim como facas, machados, foices, contas de vidro, e outros bagatellas, de que já vão fazendo seu luxo / elles procurão com tanta diligencia como os Povos civilizados; por onde se faz evidente que elles conservão 
assim como nós, o germen das paixoens, e d'ambição; ou esta se entenda pelo excessivo dezejo da gloria, e da honra ou pelo nimio dezejo dos bens. Nada mais falta do que a arte de fazer fermentar aquelle germen, $e$ de dar calor as suas paixóes para as dezenvolver do ambrião em que ainda se conservão.

Algumas Naçoens tem intentado civilizar os Indios selvagens, mas athe agora de balde, talvez, pelo pouco conhecimento, que se tem d'aquelles Povos. Hum dos meios tem sido reduzir as suas pobres Aldeias em Villas, e tirar do meio delles os vereadores, e almotaceis etcetera. $E$ faser que elles governem huns aos outros. Isto he querer principiar, por onde as Naçoens Civilizadas acabão; a arte de bem governar he a mais sublime de quantas os homens tem inventado.

O Indio Selvagem creado sempre no meio de huma liberdade absoluta, sem mais necessidades do que aquelas que elle em poucas horas satisfaz com o seu braço; educado sem alguma dependencia huns dos outros, que por isso se tratão todos d'egual, a egual, não se acomodão tão de repente com as ideias de obedecer ao seu semelhante, e este não tem mesmo a coragem de o mandar. He necessario aprencler da naturesa, que não faz as suas obras por salto; ella produz maravilhas por hum progresso continuo.

O outro meio, de que se tem usado a inda parece peor do que o primeiro; da-se hum chamado Director ahuma Povoação de Indios, dispersos, sem ideias algumas, de utillidades reciprocas: a estes Povos, aos quaes se deveria dar por Mestre da sua educação hum sabio de huma Philosophia profunda, se da pela maior parte hum homem inhabil, que de nada serve na sociedade civilisada, e que só se vai aproveitar da substancia d'aquelles mizeraveis, aos quais trata em verdadeiro Despota, e faz trabalhar como bestas de carga.

Outros Directores ainda que mais habeis, não obrão com tudo melhor, principião logo a educal'os nas Sciencias, e nas Artes proprias dos Povos civilizados: mas como vem os filhos, nem os Pais percebem o fim, e as utillidades para que os querem levar, nem tem ao redor de si objectos que lhes excite a coriosidade e o dezejo de saber, augmentão a sua moleza, enercia, mais aquelle gráo de fastio, e de aborrecimento que naturalmente atua hum principiante quando não he dirigido por huma mão habil, e prodente. Elles athe se persuadem que he mais hum tormento inventado pelas Naçoens Civilizadas para os opprimir, e flagelar: elles são os mesmos que persuadem a seus filhos, que fujão eq. não aprendão. 
E suposto que algumas vezes do meio destes filhos sahem alguns muito habeis, e que aprendem com facilidade aquillo que se lhes ensina; isto com tudo só prova que elles são capazes de huma educação, mas não que o Methodo athe agora praticado tenha sido o melhor e o mais proprio: o estado da infancia em que hainda se achão aquelles Povos ha mais de dois seculos fazem ver esta verdade.

Hum Director luctando sempre com a repugnancia dos filhos e dos Pais necessariamente ha de hir pouco a pouco afrouxando aquella primeira actividade que o pos nas esperanças de poder conseguir d'elles alguma couza: só o amor terno de huma Mãi, e a constancia de hum Pai cheios d'aquelle fogo abrazador, que só a naturesa sabe gerar, he o que os pode fazer incançaveis em procuras, bem e a felicidade de seus filhos. He pois necessario $c_{1}$ e os Pais, conheção o bem, e a felicidade de seus filhos: He necessario principiar primeiro pela educação dos Pais.

O Homem he hum composto d'alma, e de corpo, sujeito a paixoens, e a necessidades: aquelliss são maiores, ou menores, à proporção das ideas provenientes dos objectos, que o cercão, ou das que se adquirem pela educação: entre os affectos, ou paixoens há sempre alguma, ou algumas, que sobre sahem, e excedem as outras com mais força e actividade: estas são as que formão, e constituem o caracter proprio do sujeito assim como tambem o particular das Naçoens: a Arte de por em execução a maquina de cada hum sujeito consiste em pesquizar qual he a sua paixão mais forte, e dominante, achada elle pode-se diser, que está descoberta o segredo, e a molla real do seu movimento: este se poderá augmentar dando-selhe hum maior gráo de calor, athe que chegue a entusiasmo, e aquelle fogo, que arrebata o homem a sina de si mesmo: chegado a este ponto elle fará prodigios nos objectos de sua paixão.

o Indio Selvagem entre a raça dos homens parece amphibio parece feito para as aguas: he naturalmente inclinado a pesca por necessidade e por gosto: essa he a sua paixão dominante, e por consequencia a molla real do seu movimento: he por esta parte que se deve fazer trabalhar a sua Maquina, e em beneficio commum delle e de toda a sociedade. O Indio apezar da sua inclinação pela pesca incontra comtudo huma certa dificuldade em saciar a sua paixão: o methodo vagarozo, e tardio, com que elle pela falta de industria faz a sua pesca, o aparta muitas vezes d'aquillo mesmo de que elle gosta a penas contente com o pouco de que se nutre.

Mas logo que elle vir a facilidade com que o homem industrioso arma redes, forma laços, e que de huma vez 
colhe milhares de peixes; este espetaculo maravilhoso que de hum golpe de vista cahe todo de baixo da sua rude comprehensão, o encherá de alegria e de enthusiasmo: elle virá mesmo sem ser rogado lançarse no meio da Colheita e da abundancia. Este arrebatamento de gosto o hirá insensivelmente atrahindo, e convidando a viver e communicar-se com os homens d'aquella profissão que para elle se lhe representa extrahordinaria esta communicação lhe fará ver a differença do homem selvagem, e a do civilizado: pouco a pouco se hirá domesticando, e conhecendo que o homem he capaz de mais, e mais commodidades.

Logo que elle vir que aquelle superfluo, que elle athe então lançava as aves, e as feras, pelo beneficio do Sal se conserva, lhe serve de meio para adquirir as commodidades de que elle for gostando, a sua paixão irá crescendo, e a proporção obrigando-o a faser-se, mais, e mais habil: elle já não quererá ser hum simples Marinheiro, quererá logo ser hum Mestre e Senhor de huma rede: elle quererá saber quanto toca a cada hum dos Companheiros, e por consequencia se verá na necessidade de aprender Arymetica para com facilidade saber devedir e repartir: quanto elle for adiantando o seu Commercio tanto elle hade hir augmentando a sua Communicação não só as pessoas presentes mas tambem com as auzentes, d'aqui virá logo a necessidade de saber ler e escrever, e quando elle já não esteja em idade de aprender elle fará que seus filhos suprão a sua falta.

Destes Povos civilizados pela pescaria sahirão Marinheiros habeis para a navegação d'aquella Costa, e do Commercio reciproco de humas para outras Colonias. Não pequenas Embarcaçoens d'aquelle Commercio reciproco se formarão Marinheiros intrepidos, e atrevidos, capazes de arrastar-se com as maiores tormentas e de servirem athe nas grandes Naus d'alto bordo: elles formarão sem duvida huma Marinhagem escolhida. E desta sorte aquelle Indio selvagem que athe agora nem para si prestava, atravessara os Mares, virá hum dia beijar a mão d'aquella Divindade tutellar, que o tirou do nada, que por meio do Sal o fez pescador, Marinheiro, Mestre, Piloto, Commerciante, em huma palavra hum Cidadão e hum membro util a sociedade.

Elle virá aprender a obedecer, e a mandar: em tão elle encherá as ideias d'aquelles que athe agora tem inutilmente trabalhado para o civilizar. A experiencia lhe fará ver que a mesma conservação do indeviduo, e as commodidades da vida são incompativeis com huma liberdade absoluta, e com huma independencia sem limittes. Elle conhecera que he necessario perder alguma parte da 
cos de Imbiras formāo cordas muito fortes e de muita duração.

Nenhuma Nação tem hum terreno tão creador como America Portugueza: ella se comprehendo nos dois melhores Climas das Zonas torrida, e temperada, o que falta num sobeja no outro, e ambos entre si produzem mais que todos os outros da Europa juntamente. Huma grande abundancia de generos da primeira necessidade, de Marinheiros, de madeiras de consirução tudó concorre para formar huma Marinha respeitavel.

Portugal deve Iembrar-se, que a sua opolencia, a sua força, e a sua gloria farão todas produçoens da sua $\mathrm{Ma}-$ rinha: he necessario fazel'a restabellecer em todas as suas partes.

He da politica das Naçoens da Europa, principalmente das mais poderosas em Marinha vigiar q. alguma outra se não faça superior, e athe mesmo se arrogão ao direito de impedir que se faça grande. Isto he na verdade hum embaraço muito nocivo a Marinha de huma Nação menos poderosa, e que a poem muitas vezes na quasi dependência da sua rival. Huma Nação com credito tem dinheiro, tem soldados, e em pouco tempo faz marchar hum Exercito de muitos mil homens: não he assim a respeito da Marinha; ella não se faz em hum dia, não se vende, nem se empresta. Portugal porem pode por huma Marinha formidavel sem dezafiar contra si a desconfiança das Naçoens rivaes.

A dilatara Costa das Colonias do Brazil ao mesmo tempo que he defendida por muitas e escarpadas rochas, perigozos baixos; he com tudo accessivel por alguns Portos excellentes, e de muito fundo, e de largas Baías, nas quaes podem estar grande Armadas com toda a segurança abrigadas dos ventos e das tempestades. Nestes bellos Portos fazem os negociantes Navios d'alto bordo, e de grandes quilhas sem mais outra couza do que os seus maiores interesses.

Hum Negociante em hum Navio de mil caixas, lucra mais do que em dois de 500 cada hum, a marcação das velhas de seis mastros pede huma tripolação dobrada das de tres: hum a mais grande quilha tem hum maior apoio nas aguas, e por isso rolla menos, cinge-se mais ao vento, sofre mais hum temporal, chega-se mais para a linha recta, e faz huma derrota mais breve do que hum outro da metade da sua quilha dadas as mesmas circunstancias.

Se os donos dos Navios de mais d'huma certa grandeza que tiverem portinholas e quanhonheiras, e hum necessario para a artelharia, se devem premios e previlegios; terá Portugal em tempo de Guerra, quantas Fraga- 
liberdade absoluta para gozar d'outras muitas partes de huma maior liberdade relativa.

Os negros, aquelles braços feitos mais para hum trabalho continuo no meio dos ardores do Sol, do que para o frio das aguas, e que athe agora serviāo na Marinhagem, como perdidos para a lavoura, irão augmentar os produtos da agricultura. Este multiplicada Massa de produções pedirá logo hum maior numero de vasos para o seu transportes. As madeiras d'aquelle Continente que athe agora se corrompião, e destruião no lugar dos seus nascimentos, no meio d'aquelles grandes mattos: de huma extenção de mais de trinta mil leguas quadradas, serão logo postas em movimento: e ellas formarão os Navios, e as carregaçoens.

Hum dos maiores ramos do grande Commercio das Naçoens do Norte, he a venda livre das suas madeiras e muitos Pais deixão a seus filhos ricas heranças, que só consistem em Armazens de madeiras: ellas guardadas conservão-se m.to anos sem corrupção principalmente nos Paizes frios: secão-se e fazem-se melhores para as obras: deixadas porem nos dilatados Mattos d'aquelle Continente, a sua grande antiguidade, a sua muita vegetação continua em tal caso lhes abrevia a vida, e concorre mesmo para a sua total destruição: Mas não são eternas.

Alem destas cauzas ha ainda outra maior, e mais prejudicial: os grandes madeiros d'aquelle Continente ou seja pelo calor, e fertilidade do terreno, ou por qualquer outra causa, profundão pouco as suas raízes, ellas se estendem todas pela superfice da terra, aquellas Arvores sobem a huma altura extrahordinaria de mais de cento cincoenta palmos com huma grossura proporcionada: qualquer tormenta, ou hum vento mais forte as lança por terra; e o peor que com a sua queda precipitada arrastão e levão debaixo de si madeiras novas e muitas vezes mais preciosas do que ellas: estas madeiras aproveitadas augmentado hum maior numero de trabalhadores dellas, e das Embarcaçoens de transportes chegarão a Metropole por hum preço mais commodo e mais barato: a multiplicidade dos vendedores, he que sempre faz o bom mercado.

As madeiras cortadas por Monopolio ainda que ellas nada custem em bruto, ou no lugar dos seus nascimentos com tudo as transportes por si só sempre hão de chegar mais caros a feira do que sendo comprados na feira dos Lavradores d'ellas: por que o official, e o trabalhador que só corta, e conduz madeiras por conta do Monopolista não importa que ellas fação maior, ou menor despesa nos transportes, nem que ellas sejão as milhores ou as peores, antes procura porlhes, todas as difficuldades para vencer dias e jornaes. 
Não he assim o Lavrador que trabalha por sua conta, elle faz todos os esforços para ellas sejão boas, e lhes fação as menores despezas possiveis nos transportes athe a feira, ou lugar da venda; todos os dias inventa novos meios de poupar despezas, e facilitar a sua condição para conseguir hum maior lucro: e esta he a razão por que as obras publicas ordinariamente se remattão a quem as faz por menos.

$O$ interesse foi sempre o mestre da indústria; elle descubrirá novos caminhos fará Navegáveis os Rios, fará serrar as Madeiras nos lugares em que forem cortadas para mais facilmente serem conduzidas, ou em pranchas grossas, ou em taboas já proporcionadas à bitola para as tirar ou em carretões ou em sima de costas huma ahuma athe as por a borda dos grandes Rios ou ainda de pequenos Ribeiros, e esperar o tempo das agoas para as faser des. cer, ou soltas, ou presas em balsas, ou jangadas conforme a grandeza dos Rios etcetera.

Os mastros de vinte quatro palmos, e mais que se tirão de Riga na Livonia vem das mattas, que se cortão na Provincia da Ukrania, e inda mt.o mais adiante de sorte que he necessario esperar o Inverno para os tirar arrastando sobre a neve, ou sobre o gello, athe as Margens do Rio d'Una donde descem para chegar a Riga athe ao mez de Junho. Todo este maquenismo só pode ser executado por aquelles que cortão e transportão as madeiras: e por isso he necessario deixar-lhes a liberdade de fazer $\sigma^{\prime \prime h}$ por sua conta o lucro, e a despeza.

Os muitos cortes de madeiras no Brazil não poderião com tudo fazer huma falta muito sensivel ao Estado por que alem de serem immensos aquelles matos / que para os cortar todos seria necesario mais de dez seculos / a fertilidade do Paiz irá pela outra parte suprindo pela continuada produção de outras muitas arvores. Mas ainda no caso de se seguir com effeito huma sencivel falta de madeiras de construção pelos repetidos cortes, seria necessario calcular se ellas deixadas nos mattos disposta a apodrecer, a cahir, e a destruir as outras darão hum maior lucro ao Estado do que reduzidas succesivamente em $\mathrm{Na}$ vios para o Commercio, e defeza da Nação.

As madeiras de construção; o linho, o Canhamo e outros generos desta naturesa que tem feitas ricos as $\mathrm{Na}$ çoens do Norte, são muito melhores, e em muito maior abundancia nas Colonias do Brazil: alem dos generos conhecidos na Europa para as Cordonias, ha nellas outros muitos talvez milhores: o Imbe, o Taecum, de que os Indios fazem as Cordas dos seus Arcos, o Crata, a Guaxima, e outras diversas qualidades de baixo nome generi- 
tas quizer e muitas Naus, sem lhes correr o risco, nem cauzar siume as Naçoens rivaes. $\mathbf{E}$ se aos ditos Negociantes se der a artelharia necessaria sem mais outra obrigação do que a de darem conta della todas as vezes que se lhe pedir; será respeitada em todo o Oceano a Bandeira Portugueza; e poderão servir athe de guarda Costa aos Navios mais pequenos: o negocio será florente; a Marinha será formidavel.

A grande exportação de viveres e dos generos das Colonias para a Metropole necessariamente hade produzir huma grande exportação das manufacturas da Metropole para as Colonias, o baixo preço das carnes, e dos peixes salgados do trigo, do Arroz, das farinhas etcetera das Colonias fara sem duvida mais comoda a mão d'obra do fabricante da Metropole: esta vestirá aquellas com profusão; aquellas sustentarão a esta com abundancia; e todas farão cahir por terra o contrabando do Estrangeiro, que só se nutre da nossa falta, e da Carestia das nossas manufacturas.

He certo que se ha agricultura, e ha produção dos generos das Colonias, se der toda a extenção de que ellas são capazes; a Metropole não as poderá consumir todos, nem dar-lhes em manufacturas hum egual saldo das suas receitas; ella será mesmo devedora as Colonias: mas que prejuizo se seguirá disto a Metropole? Quanto mais ella abundar em generos das Colonias tanto ella terá mais que vender aos Estrangeiros: os generos das Colonias são preciozos, são da primeira necessidade: Os Estrangeiros necessitão, não se podem dispensar delles.

A Metropole será sim devedora as Colonias; mas ella será em dobro credora aos Estrangeiros; ganhará nas compras, ganhará nas vendas, ganhará nos fretes, e nos transportes para todas as partes pela extenção da sua $\mathrm{Ma}$ rinha. Que importa que a Mái deva a seus filhos, quando ella he em dobro credora aos Estranhos; E pelo contrario a Metropole não pode ser credora das Colonias, sem ser devedora aos Estrangeiros, pois que ella não tem bastantes viveres com que se sustente, nem mesmo fabricas, com que se vista.

Conheço que se as Colonias cultivarem com abundancia este, ou aquelle genero que se cultiva na Metropole virá o genero da Metropole a abaixar de preço a proporção da abundancia do das Colonias: mas isto em nada poderá prejudicar; nem ainda a algum particular Lavrador da Metropole.

Por que em primeiro lugar abaixado hum genero pela sua abundancia principalmente sendo da primeira necessidade, também os outros generos hão de necessariamente abaixar pela razáo da muita abundancia; e tudo 
virá a ficar em equilibrio na Metropole; o Fabricante comerá sim a melhor preço; mas elle dá em troca ao Agricultor a sua mão d'obra a melhor mercado; da mesma sorte o Lavrador, o Commerciante etcetera.

Em segundo lugar será muito útil ao todo da Nação, por que terá hum superfluo muito abundante; e em dobro para vender a toda a Europa; e ainda a todo o Mundo por hum mais baixo preço athe se foi necessario arruinar os generos da agricultura das Naçoens rivaes, que nos pertenderem disputar a preferencia.

A arte de Negociante consiste em se fazer Senhor deste, ou d'aquelle ramo de Commercio para o que he necessario da-lo a tambem mercado que nenhum outro possa jamais entrar com elle em concorrencia.

A Metropole, e as Colonias primeiramente a respeito da agricultura, e de tudo o que he produção da terra se cleve considerar como huma só fazenda de hum mesmo agricultor, cujo fim he conservar a sua caza em abundancia, e ter hum grande superfluo para vender os estranhos: ao possuidor de muitas Quintas não importa, nem deve importar, que esta, ou aquella lhe renda mais, só sim que todas ellas the rendão muito.

A Metropole por isso que he mãi deve prestar as Colonias suas filhas todos os bons officios e soccorros necessarios para a defeza e segurança da sua vida, e dos seus bens, mantendoas em huma socegada posse, e fruição dessa mesma vida, e desses bens. Estes beneficios pedem eguaes recompensas, e ainda alguns justos sacrificios: e por isso he necessario que ás Colonias tambem da sua parte sofrão; primeiro, que só possão Commerciar directamente com a Metropole excluida toda. e qualquer outra Nação ainda que lhes fisessem hum Commercio mais vantajozo. Segundo, que não possão as Colonias ter fabricas primeiramente de lãa e seda, e que sejão obrigadas a vestir-se das Manufacturas da Metropole desta sorte os justos interesses e as relativas dependências mutuamente serão ligadas.

Em huma palavra quantos os interesses e as utilidades da Patria mãi se enlaçarem mais com as das Colonias suas filhas tanto ella será mais rica, o quanto ella dever mais as Colonias, tanto ella será mais feliz, e vivirá mais segura. O Credor sempre olha para o seu devedor como para a sua fazenda: elle concorre para o seu augmento, e não o quer ja mais arruinar, nem perder de vista: $O$ devedor porem olha para o seu Credor quasi como hum Escravo para seu Senhor, e quanto elle se faz menos soluvel tanto elle procura mais a occasião de lhe fugir.

O homem que vive no meio da pobresa, da oppressão, e da mizeria amaldiçoa ainda aquelles que o gerarão, abor- 
rece a vida, revolta-se contra todos, contra si mesmo, mata-se e se despedaça: e pelo contrario o homem que vive na abundancia logo se lembra de huma comp.a honesta, que lhe seja amável, e que o ajude a viver contente: e quando elle se vê reproduzido em seus filhos adora o Creador, e beja a mão bem feitora, que os proteje: respeita a Religião, respeita as Leis, e he o primeiro que se interessa na conservação da paz publica, da qual necessariamente depende a sua particular, e da sua familia.

Só teme quem tem que perder, quem mais tem que perder, mais teme quem mais teme mais obedece. He pois necessario que os interesses da Metropole sejão inseparaveis dos das Colonias; e que sejão tratados sem revalidade. Quanto os vassallos são mais ricos tanto a Soberana he muito mais.

Estes serão infalivelmente os fructos que ham de produsir os beneficios que se repartirem por aquelles Povos que por natureza são doceis, manços, fieis, e agradecidos; se este for o lugar para tecer o seu elogio bastaria a simples narração da sua historia para fazer ver as muitas e muitas vezes que elles a custa de seus bens, e do seu sangue remissão aquelles Dominios para os restituir aos seus legitimos Soberanos: os inimigos do Estado, aquelles mesmos, que soffrerão os mais pezados golpes dos seus braços não poderão ja mais negar esta verdade.

Aquelles Povos que pela só edeia da vontade dos seus Soberanos e de que os amão como filhos, se enchem de hum enthusiasmo sem lemittes: os seus curações abrazados tem feito prodigios de valor, e heroismo. Elles ainda são os mesmos filhos; e incessantemente dão as graças a benigna mão do Omnipotente, que lhes deu por Soberana huma Mãi bemfeitora: elles a respeitão como a Lugar-Tenente de Deus na terra e como hum dom preciozo do Ceu, Santo, Justo e Bom.

Bibliotheca Publica Eborense.

Cod. CXVI $-2-13-$ a N. 25 . 